\title{
TODOS LOS CUERPOS. EL CUERPO EN TELEVISIÓN COMO OBSESIÓN HIPERMODERNA
}

Inmaculada Gordillo y Virginia Guarinos (eds.)

Babel Editorial. 2009. Córdoba.

\author{
Miguel Vidal Pérez \\ Universidad de Sevilla \\ http://dx.doi.org/10.12795/AdMIRA.2010.01.14
}

¿Cuántos cuerpos caben detrás de una pantalla? ¿Uno? ¿Ninguno? ¿Cien mil? Todos los cuerpos presenta al lector interesado en el panorama audiovisual un metafórico animalario donde confluyen dos de las cimas de la sociedad postmoderna contemporánea: el culto al cuerpo y al amparo de la televisión. No existen dos entes que representen de forma tan meticulosa la silueta de esta obsesiva sociedad hipermoderna.

Los diecinueve artículos que conforman la obra final se entrelazan y cohesionan a partir de una introducción en la que sus editoras atrapan al lector en una tela de araña tejida desde la "lógica de la seducción" (Lipovetsky). Si vivir hoy es hacerlo dentro de la sociedad del hedonismo y de la moda, la televisión se convierte en médium que refleja y a la vez es modelo de un Narciso cuyas aguas se cristalizan en la pantalla del televisor. Tres son los hilos de Ariadna para escapar victoriosos del laberinto de cuerpos que encontramos: I. Cuerpos de verdad. El cuerpo en programas no ficcionales; II. Cuerpos de ficción. El cuerpo en las series televisivas y III. Cuerpos para vender. El cuerpo en la publicidad.

En la primera sección destacaremos "El cuerpo construido y el cuerpo vigilado en el docudrama televisivo" donde Gordillo y Ramírez Alvarado recorren -entre infinidad de referencias culturales: Pigmalión, Frankenstein, Fausto- la "tiranía" que conllevan los llamados "productos milagro" y el ideal de belleza y lozanía que lucha por imponerse pese al implacable paso del tiempo (Extreme Makeover). Bajo la catalogación de "cuerpo vigilado" se referirá a las múltiples modalidades del Big brother que la "telerrealidad" se ha encargado de promover desde innumerables contexto y cadenas. La respuesta a dicha tesitura la encontrará en el artículo de Pérez Henao quien sostendrá que el cuerpo que contemplamos en el reality no es, paradójicamente, un cuerpo real, sino un cuerpo-narrado (acaso mentiroso) que se construye "desde las entrañas de la institución televisión” (p. 59).

En el capítulo referido a los Cuerpos de ficción resulta lúcido el análisis de Cobo-Durán llevado a cabo en su artículo "Guapos y bellos. El Adonis televisivo, una especie en peligro de expansión”. En él reformula como sigue la vieja máxima latina: corpore sano in corpore bello. La mente se hunde en las aguas del Leteo. Aludiendo a míticas series juveniles de los noventa enfatiza la tríada que coliga belleza, dinero y sexo como claves del triunfo moderno. En una clasificación no exenta de referencias filosóficas (Platón, Kant, Tatarkiewicz) disecciona la realidad televisiva entre cuerpos mudos, semiparlantes y vivos. En este apartado ficcional de la obra merece una mención destacada la reflexión ética de Jacqueline Sánchez ("El cuerpo en los programas infantiles: estética y valores") quien pone de relevancia una de las grandes taras de la televisión actual: "En relación con el contenido se observa una tolerancia a las acciones violentas que sigue siendo asombrosa" (p. 265). Su propuesta alternativa radica en una renovada alfabetización -audiovisual- que debería conducir a niños y jóvenes hacia una lograda mayoría intelectual de edad (televisiva). 
La tercera sección de este recopilatorio constituye la lente de aumento que agiganta y magnifica nuestras virtudes y vicios con respecto al binomio corporeidad-televisión. La publicidad nos regala -o mejor dicho "nos vende"- un extenso muestrario de ejemplos hiperbólicos, desmesurados y desmadrados del cuerpo como protagonista solitario de un sujeto descentrado. En Cuerpos para vender resulta nostálgico el paseo evolutivo que Checa Godoy realiza por los entresijos de nuestros anuncios de la infancia. La travesía desde el cuerpo inexistente -la televisión de la dictadura- hasta los confines de un cuerpo que deviene imprescindible para colocar toda clase de artículos y baraterías. La publicidad es también el receptáculo en el que con menor problema se mantienen los anacrónicos estereotipos de género: higiene, belleza y la mujer-cuerpo. Una mención especial merece la prosa de Juan Rey y Manuel Garrido interesados por un producto aparentemente menor -la televenta- pero cuyas implicaciones nos conducen entre aparatos de gimnasia y cremas milagrosas anunciadas a deshora hasta los cuerpos manufacturados del presente.

Quizás no hubiese sobrado una conclusión que volviese a abrazar las múltiples posturas, matiz que realizamos ante el buen sabor de boca que dejó la introducción "Variaciones sobre lo corpóreo en televisión”. La obra es completa, multiforme y amena por la brevedad de sus artículos. Lectura recomendada y plástica por los constantes ejemplos que incluye.

Todos los cuerpos. El cuerpo en televisión como obsesión hipermoderna es, si se nos concede la licencia, una lucha cuerpo a cuerpo en un doble sentido. Primero representa la batalla que cada sujeto libra con sus propias convicciones intelectuales, es decir, consigo mismo. En segundo lugar, enfatiza la pelea que cada uno de nosotros vivimos a diario con los otros cuerpos, con un mundo en el que interactuamos y nos conformamos. Y ahora replantearemos la pregunta inicial: ¿cuántos cuerpos caben detrás de una pantalla? Todos los cuerpos. 